\title{
Espelhos do mal: arquivo e corrupção em Sade
} ALINE LEAL FER NANDES BARBOSA ${ }^{I}$

\begin{abstract}
"Será enviado um mensageiro ao sr. Lenormand, mercador de madeira... para pedir-lhe que venha ele próprio, com uma charrete, buscar meu corpo para ser transportado... ao bosque de minhas terras da Malmaison... onde quero que seja colocado, sem cerimônia alguma, na primeira mata de corte cerrada que se encontra à direita no dito bosque... Minha fossa será aberta nessa mata pelo caseiro da Malmaison, sob a inspeção do sr. Lenormand, que só deixará meu corpo após tê-lo colocado dentro da dita fossa... A fossa, uma vez recoberta, serão semeadas bolotas de carvalho a fim de que, em seguida, o terreno da dita fossa se achando reguarnecido e a mata se achando cerrada como era antes, os vestígios de meu túmulo desapareçam da superfície da terra, como me gabo de que minha memória se apagará do espírito dos homens.”
\end{abstract}

(Testamento do Marquês de Sade citado na revista Acéphale).

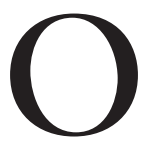

RITUAL que Sade (1740-1814) deixa registrado em seu testamento parece ter como objetivo final o apagamento do indivíduo, seu descolamento da memória da humanidade, o que soa coerente com o projeto de desindividuação e de dissolução do sujeito na atividade erótica ${ }^{1}$ e, mais radicalmente, com o projeto de sua destruição na obra sadiana, arruinado como a religião, o idealismo, os costumes, as virtudes, a família.

Seus livros dão testemunho desse desejo de aniquilação. Em A filosofia na alcova - os preceptores libertinos (1795), encena-se uma didática das práticas lúbricas para a jovem Eugênia, alternando cenas de libertinagem com reflexões filosóficas. Em Os infortúnios da virtude (1787-1788), os vícios sempre prosperam, ao passo que as fraquezas da virtude sucumbem inevitavelmente, para não falar de Os 120 dias de Sodoma (1785), em que se investe insistentemente na necessidade imperiosa de afrontar valores e de destruir seus significados, apostando na capacidade do autor de renovar seu motivo principal ao infinito.

Georges Bataille (1897-1962), no ensaio que dedica a Sade em A literatura e o $\mathrm{mal}^{2}$ discorre a respeito desse testamento, na chave do que ele chama de "vontade de destruição de si”, como sentido da obra sadiana: “[...] o sentido de uma obra infinitamente profunda está no desejo que o autor teve de desaparecer (de se dissolver sem deixar nenhum vestígio humano): pois não havia nada mais à sua altura” (Bataille, 2015, p.104-5).

É verdade que, apesar da obra monumental que Sade produziu, a possibilidade de apagamento de seu nome da memória da literatura ocidental não lhe passou longe. Sabe-se que morreu acreditando que os manuscritos de Os 120 
dias de Sodoma - um rolo de 12 metros de comprimento por 12 centímetros de largura $^{3}$ - haviam sido perdidos em 14 de julho de 1789, durante o levante da Bastilha, onde Sade se encontrava preso havia cerca de dez anos. Doze dias antes da revolução, entretanto, ele teria sido transferido para o hospício de Charenton, julgado louco por berrar de sua cela que degolavam prisioneiros no interior das fortalezas. Os manuscritos - escondidos pelo marquês entre as pedras de sua masmorra como plano para reduzir a possibilidade de serem apreendidos, ciente que estava de seu conteúdo inaceitável - desapareceram. Sabe-se que foram recolhidos por um tal de Arnoux de Saint-Maximin e levados à posse da família dos Villeneuve-Trans, de origem nobre, onde permaneceram durante três gerações, até serem vendidos a um colecionador alemão. ${ }^{4}$

Foi apenas no início do século XX, tendo passado o século XIX na interdição e no ostracismo, que a obra de Sade foi redescoberta. Em 1929, Maurice Heine (1884-1940) recuperou os manuscritos dos 120 dias e os repatriou à França, publicando, ao longo da primeira metade da década de 1930, uma edição cuidadosa em três volumes, ainda hoje referência para edições subsequentes. Antes disso, o poeta Guillaume Apollinaire (1880-1918) foi o principal introdutor dos livros de Sade na cena literária francesa, até então um escritor praticamente desconhecido. No prefácio biográfico da antologia que publicou dos textos de Sade, em 1909, Apollinaire o chamou de o "espírito mais livre que já existiu na terra", embora o marquês tenha ficado quase trinta anos de sua vida encarcerado em onze instituições.

Há ainda mais uma reviravolta: em 1982, o manuscrito foi roubado e vendido a um colecionador suíço de livros eróticos. Somente em 2014 voltou à França, como um dos manuscritos mais caros da história, adquirido por $7 \mathrm{mi}$ lhões de euros pelo bibliófilo francês Gérard Lhéritier, diretor do fundo Aristophil e do Museu de Letras e Manuscritos de Paris. A história apresenta ainda outros pontos de virada, como a detenção do próprio Lhéritier, acusado de fraude, e a tentativa de venda dos manuscritos pelo fundo. Declarado tesouro nacional pelo governo francês, entretanto, os rolos foram impedidos de ser leiloados.

Simone de Beauvoir (1908-1986), no longo ensaio Deve-se queimar Sade (Beauvoir, 1961), afirma que é possível folhear obras minuciosas sobre as "ideias do século XVIII" e a "sensibilidade do século XVIII" sem encontrar vestígios do maior representante da literatura libertina europeia desse século. Seria esse "silêncio escandaloso", segundo a autora, que faria os devotos de Sade saudarem-no como "genial profeta", cuja obra anunciaria, ao mesmo tempo, Nietzsche, Stirner, Freud e os surrealistas. Tal divinização do "divino marquês", no fim das contas, dificultaria sua compreensão, ao tratá-lo com mais adoração do que com rigor, mais como ídolo do que como homem, culto que trai o caráter volúvel e contraditório de sua obra e de sua figura histórica.

Georges Bataille também parte do mote incendiário que tantos nomes pretendeu levar à fogueira no ensaio dedicado a Franz Kafka, em que indaga: 
"Faut-il brûler Kafka?". Apenas o título já sinaliza o desejo de consumação de seus livros pelo fogo, tarefa que relegou ao amigo Max Brod. Bataille, por sua vez, aponta para o caráter equívoco dessa nomeação: havia confiado a execução do auto de fé àquele de seus amigos que o avisara que se recusava a executá-lo. Não morreu, entretanto, sem exprimir a vontade de aparência decisiva: jogar no fogo aquilo que deixava (Bataille, 2015, p.143).

É curiosa a dramaturgia que Sade criou para sua morte, que tenha se dado ao trabalho de deixar registrada a teatralização de seu enterro, saída literária que contribui para a consolidação de sua memória. Apesar do desejo de desaparecer da face da terra, Sade produz, ao escrever, provas de sua existência, transmitindo para o futuro um arquivo grandioso, sem horizonte de esgotamento, indicando a tensão entre a vontade de desaparecimento (do autor) e a vontade de preservação (da obra). E, assim como o desejo final de Kafka não foi respeitado e seus manuscritos sobreviveram, Sade foi enterrado no cemitério do asilo de Charenton, em uma cova com uma cruz e sem nenhuma inscrição. Mais que isso: sua obra e sua biografia permaneceram.

Jean-Jacques Pauvert (1926-2014), famoso editor de clássicos da literatura erótica, então com apenas 20 anos, foi o primeiro a editar oficialmente a obra completa do marquês na França, entre 1945 e 1947, começando com $A$ história de Juliette. Foi, por isso, processado pelo Ministério Público francês, ganhando a causa em 1958. Depois de um período de ostracismo, perseguição e clandestinidade, em 1990 a obra sadiana passa a fazer parte da famosa coleção francesa La Pléiade, reservada aos mais renomados autores franceses. O slogan da campanha para divulgar o lançamento indica o caráter profano dessa consagração: “L’enfer sur papier bible".

Mas que tipo de escritor é esse que ousa renegar a própria posteridade? Para Theodor Adorno (2003, p.62-3), nenhuma obra de arte moderna que tenha algum valor deixa de encontrar prazer na dissonância e no abandono, e afirma que os romances que realmente contam se assemelhariam a "epopeias negativas". Nesse sentido, a literatura moderna se fundamentou em torno do movimento de transgressão do estilo racionalista e edificante que vigorou no século XVIII. Sade, ao mesmo tempo herdeiro e traidor do pensamento das Luzes, seria precursor desse desejo de aniquilamento, um empreendimento ético-estético que visava a uma corrupção das instituições pelo corpo, pela letra e pela lei, apostando na soberania do indivíduo sobre as normas. Em Os 120 dias, Sade (2017, p.62) reconhece o ineditismo de sua subversão na história da literatura: "Agora, amigo leitor, prepara teu coração e teu espírito para o relato mais impuro já feito desde que o mundo existe, pois não há livro semelhante nem entre os antigos nem entre os modernos".

Em sua literatura, encontra-se uma insistente degeneração do corpo e das práticas que lhe são instituídas. Só para citar um exemplo em meio a incontáveis insubordinações, em A filosofia na alcova, Mme de Saint-Ange relata para a 
pupila Eugênia uma fantasia extraordinária: "O gosto do meu marido consiste em ser chupado, e eis o singularíssimo episódio que ele lhe acrescenta: enquanto, curvada sobre ele, minhas nádegas em cheio sobre seu rosto, eu aspiro com ardor a porra de seus colhões, tenho de cagar-lhe na boca! Ele engole" (Sade, 2015 , p.60). Põe-se a filosofia ao exame do corpo, deslocando a soberania da razão - da cabeça -, como produtora de reflexões, para o baixo ventre. Não à toa Bataille e o grupo que o circundava - Pierre Klossowski (1905-2001), André Masson (1896-1987) - elegeram a figura do acéfalo para "encabeçar" (sic) a revista e a comunidade de cunho iconoclasta e antirracionalista que fundaram em 1936 com a sentença: "O homem escapou da sua cabeça como o condenado da prisão" (Revista Acéphale, v.1 [A conjuração sagrada], 1936). Não escapa à lembrança a guilhotina do incorruptível Robespierre que fez carreira no século XVIII e da qual Sade escapou por um triz.

Imoral e indigno em qualquer regime, Sade foi perseguido pela monarquia (Antigo Regime), pelos revolucionários vitoriosos de 1789 e, depois, por Napoleão. Na espécie de panfleto que se encontra após o quinto diálogo de $A$ filosofia na alcova, intitulado "Franceses, mais um esforço se quereis ser republicanos", Sade estende a todos os cidadãos franceses a educação que estava sendo aplicada no quarto de concentração da luxúria. A principal lição consistirá em eliminar a religião e os costumes a fim de contribuir para o progresso das Luzes. O marquês reconhece, conforme aponta Contador Borges no posfácio da tradução de A filosofia na alcova, ${ }^{5}$ que a Revolução Francesa e o Iluminismo haviam realizado um bom trabalho no intuito de eliminar as trevas da ignorância, da superstição e do preconceito, mas era preciso ir um pouco além, encore un effort, para que o homem atravessasse uma radical transformação, o que passaria, necessariamente, por um processo de destruição (Borges, 2015, p.217).

Jacques Derrida (2001), em Mal de arquivo: uma impressão freudiana, trata da pulsão de morte - ou pulsão de agressão, ou pulsão de destruição - como a variável fundante do "mal de arquivo", que seria um questionamento crucial do conceito de arquivo. Para Derrida (2001, p.21), "ela [a pulsão de morte] trabalha para destruir o arquivo: com a condição de apagar mas também com vistas a apagar seus 'próprios' traços - que já não podem desde então serem chamados 'próprios"'. O autor realiza uma desconstrução da concepção clássica de arquivo, em que a noção de conservação do passado cede lugar a uma abertura ao futuro, à construção de novos enunciados, sob o signo do apagamento e da destruição.

O arquivo, como expõe Derrida, está referido à palavra grega arkhé, que condensa um duplo significado: o de começo, seu sentido ontológico, e o de comando, princípio nomológico de autoridade. Assim, trata-se de definir, de um lado, onde e quando começa o arquivo e, de outro, quem o comanda. A consignação a que está sujeito, por sua vez, ordenaria e classificaria os signos e os documentos, submetendo-os a um guardião e a um intérprete. Derrida (2001, p.22-3) afirma: 
Se não há arquivo sem consignação em algum lugar exterior que assegure a possibilidade da memorização, da repetição, da reprodução ou da reimpressão, então lembremo-nos também que a própria repetição, a lógica da repetição, e até mesmo a compulsão à repetição, é, segundo Freud, indissociável da Pulsão de Morte. (grifo do original).

Nesse sentido, a consignação, ou seja, a reunião e a reorganização dos signos deslocados de seu lugar originário sob um comando interpretativo pavimentam uma nova configuração, embora igualmente sujeita a uma violência instituidora: a escolha da instituição, a forma, a língua, a estrutura de arquivo, a demanda, a lei. Não há, portanto, arquivo que não se submeta aos imperativos ontológicos e nomológicos, às dimensões cognitivas, éticas e políticas. Contudo, essa finitude - como condição de possibilidade do arquivo - é potencializada pelo processo de repetição do ato arquivante, apontando para a infinitude do futuro.

Eliane Robert Moraes (2003), no artigo “A prosa degenerada”, observa que o escândalo de Sade não foi escrever obras obscenas, o que aliás era corrente na literatura libertina setecentista, mas sim deslocar o pensamento iluminista para a alcova lúbrica, aproximando a filosofia do erotismo. Ao dar à filosofia a prerrogativa de um domicílio e de um intérprete outros - a alcova e o grupo de libertinos -, o marquês parece radicalizar essa consignação, reunindo princípios aparentemente inconciliáveis e investindo uma medida de destruição no que é da ordem da conservação. A pulsão de morte relacionada por Derrida ao mal de arquivo possibilitaria tanto o esquecimento quanto a renovação do arquivo pelas novas consignações, que seriam, portanto, a condição de possibilidade de acrescentar novos arquivamentos.

Ao ter conhecimento de que os rolos de Os 120 dias de Sodoma haviam desaparecido, Sade se exprime assim a esse respeito: "Meus manuscritos, cuja perda me faz derramar lágrimas de sangue!... nunca poderei descrever para vós meu desespero por essa perda, ela é irreparável para mim" (apud Bataille, 2015, p.103). Segundo nos conta Bataille (2015, p.103), aparentemente foi a perda de Os 120 dias que levou Sade a retomar, numa versão escandalosa, a história de Justine e a lhe dar como sequência a história de Juliette: “[... não dispondo mais do testemunho essencial que quisera dar, ele devia pensar em substituí-lo por outra obra tão completa quanto aquela". Tratava-se, portanto, de reconstruir os elementos que elaborara em Os 120 dias de forma expansiva e que supunha ter sido perdida para sempre. O princípio de destruição do arquivo indica, nessa passagem, sua potência incubadora de novas escritas, geradas nos rastros das lágrimas de sangue. É preciso continuar escrevendo em face da ameaça da integridade do manuscrito, pressionado entre as pedras da masmorra da Bastilha, denotando a fragilidade e o risco do arquivamento.

No ensaio “A dissolução universal”, Octavio Paz (1999) apresenta a impressionante contemplação do sistema sadiano, sua orgulhosa prisão: 
[...] coerência desolada, vertiginosa fortaleza. Sensação de angústia e total desamparo; estamos trancados, mas nossa prisão não tem limites; nunca acabaremos de percorrer essas masmorras e corredores sem fim. Nenhum muro nos esmaga, e sim o horror vazio. Estamos cercados de infinitos, um infinito feito de repetições. Uma a uma, as construções de Sade se derrubam. Nada exterior as derruba: o dinamitador é o seu próprio pensamento. Sade nega Deus, as morais, as sociedades, o homem, a natureza. Ele nega a si próprio e desaparece por trás de sua gigantesca negação. (Paz, 1999, p.90)

A bela imagem de Paz aponta para a interminável tarefa de percorrer os vãos e os desvios dessa prisão a que se estaria confinado irremediavelmente, indicando talvez um falso dilema proclamado por seus prisioneiros, ocupados em denunciar sua falta de liberdade ou pelo menos evidenciando a estratégia do divino marquês de contornar essa instância limitadora. Seria essa prisão a vida, a linguagem, as instituições, o sistema? Será o arquivo igualmente um exemplo de aprisionamento, tendo em vista sua geografia de limites definidos, sua organização e interpretação baseadas em uma autoridade? Entretanto, ainda que se aponte para a finitude do arquivo, cerceamento inerente à sua constituição, para o princípio da tradição interpretativa, há uma margem que se estende a uma abertura infinita, futuro de promessa inalcançável, terra que jamais se avista, indicando um limite de fronteiras ilimitadas. Ao inserir a pulsão de morte como constitutiva do mal de arquivo, Derrida parece apontar para o sentido de uma insistente abertura do vir-a-ser.

Se alguns pensadores do século XX denunciaram a linguagem como uma "camisa de força", na medida em que não permite dizer, mas obriga a dizer, segundo a célebre proposição barthesiana em $O$ gran zero da escritura (Barthes, 2004), Paz indica que a prisão sadiana apresenta uma dimensão labiríntica. Para alcançar o lado de fora - liberdade impossível -, é preciso empreender uma tarefa exaustiva, esquadrinhar milimetricamente toda a extensão da língua, transformando esse percurso em literatura. Se autores - sobretudo do século XX - buscaram a vertigem do fora pelas bordas da linguagem valendo-se não raro do silêncio ${ }^{6}$ para tanto, o marquês, por seu turno, lançou mão da estratégia verborrágica, enciclopédica, de elencar, classificar, contabilizar as possibilidades que se desdobram ad infinitum. Embora esse infinito, em tese, tenha um fim, quem poderá de fato extinguir a vastidão de seu território? A tarefa será sempre a de um prisioneiro.

Tal imagem nos leva a pensar em "A biblioteca de Babel", conto de Jorge Luis Borges (1999). Tem-se a descrição de sua superfície: "No vestíbulo há um espelho, que fielmente duplica as aparências. Os homens costumam inferir desse espelho que a Biblioteca não é infinita (se o fosse realmente, para que essa duplicação ilusória?), prefiro sonhar que as superfícies polidas representam e prometem o infinito..." (Borges, 1999, p.38). A biblioteca de Borges abrange o universo todo, todos os livros possíveis formados por meio de todas as combinações possíveis das letras do alfabeto: uma conta de escala não humana. 
No ensaio "Sade, a felicidade libertina", Eliane Robert Moraes (2006) apresenta a alcova libertina como um lugar pequeno, privado e íntimo, mas cujas dimensões parecem se ampliar indefinidamente. A função dos espelhos - presença obrigatória na alcova - multiplicaria o efeito das cenas libertinas de modo que atingisse todos os que se encontrassem presentes e mesmo aqueles que não participassem diretamente dos atos lúbricos.

\section{Espelhos do mal}

O espelho proliferador de imagens é também construtor de mundos, de acordo com Michel Leiris (2001) em O espelho da tauromaquia. ${ }^{7} \mathrm{O}$ autor privilegia o momento de breve paroxismo, que "não dura mais que um relâmpago e que deve seu fulgor ao fato de estar na encruzilhada de uma união" (Leiris, 2001, p.11). Lugares em que o homem tangencia o mundo e a si mesmo, como o gesto do torero conduzindo suavemente o touro nas dobras românticas de sua capa. Acontecimentos que suscitam a "sensação de que sua função na ordem geral das coisas consiste em nos pôr em contato com o que há em cada qual de mais profundamente íntimo, de mais quotidianamente turvo e mesmo de mais impenetravelmente oculto" (ibidem). Os artistas seriam, nesse sentido, agenciadores de experiências cruciais, de revelações e, tal como a tauromaquia, os esportes ou os jogos (em especial os jogos de azar), a atividade passional e genital, construtores de mundos, "artesãos lúcidos de nossas revelações" (ibidem, p.74). No entanto, é preciso que esses espelhos - esses mundos - venham acompanhados de alguma rachadura, algum elemento suscetível de fazer despontar o vício por meio da beleza a fim de elucidar nossa comunhão futura com a morte.

Michel Leiris faz referência ao ideal poético de beleza de Baudelaire, em que a modernidade circunstancial e transitória mancharia a beleza abstrata e indefinível, um rosto feminino ardente e triste, amargo e voluptuoso. Ao reforçar a medida perturbadora dessa noção, sua falha ou passagem de infortúnio, Leiris parece incorporar os acidentes da matéria à matéria, fazer coincidir o princípio da destruição no que se conserva. Será justamente essa brecha o fundamento da ideia de beleza, assim como a corrupção do arquivo - o mal de arquivo, suas rasuras e lacunas, suas falhas e descontinuidades - será seu princípio arquivante, sua possibilidade de existência, talvez sua relíquia. A pitada de veneno que assegura a noção de beleza, porém, tem uma medida insondável: o coeficiente dessa equação ou sua proporção alquímica cabe a cada construtor de espelho, um cálculo lançado ao futuro.

Em "Sade, um humanismo possível?", Michel Delon ${ }^{8}$ (2015) conta a história do envio de um exemplar autografado por Leiris de $O$ espelho da tauromaquia (1938) ao já citado Maurice Heine, editor na França dos Infortúnios da virtude e de Os 120 dias de Sodoma. De acordo com Delon, Heine teria agradecido o presente confessando, entretanto, uma "'prevenção capital' contra todos os combates de animais", dizendo que Leiris havia "analisado admiravelmente o menos admirável de todos os códigos". Fica evidente, pelo comentário contra- 
riado de Heine, que o procedimento sadiano, sua medida extrema de crueldade, atuaria no registro ficcional, que seus espelhos construídos antes criam que refletem imagens do mundo, que a ferida dos corpos não se corta na carne - menos ainda na carne de animais inocentes. Leiris teria destacado o horror sangrento enquanto Sade haveria de anunciar o horror sonhado, sublinha Delon $(2015$, p.37).

\section{Arquivos do mal}

Haverá mais sadismo em um romance de Sade ou em práticas sádicas de uma vida? Ilse Koch, ${ }^{9}$ a abominável "cadela de Buchenwald”, esposa de Karl Otto Koch e comandante dos campos de extermínio de Buchenwald e Majdanek, tornou-se sinistramente famosa por colecionar como souvenir pedaços de peles tatuadas de prisioneiros. As peles viravam capas de livro, luvas, abajures e lustres; órgãos e cabeças encolhidas eram expostos como troféus; polegares mumificados, usados como interruptores. Tratada por sádica pela história, comparada às heroínas criminosas do Marquês, em que medida será de fato uma aliada de Sade, uma de seus pares no domínio da crueldade? Em Sacher-Masoch: o frio e o cruel (1967), Gilles Deleuze (2009) elabora a ideia de que os dois autores - Sacher-Masoch e Sade -, ao darem seus nomes para designar duas perversões básicas (o masoquismo e o sadismo), assumiriam o papel de médicos, e não de doentes: "O médico não inventou a doença. Mas separou sintomas até então associados, agrupou outros antes dissociados, ou seja, constituiu um quadro clínico profundamente original” (Deleuze, 2009, p.17). Será Sade médico do sadismo, na medida em que destina à dimensão literária uma prática interditada ao plano do real?

No artigo "A fera pensante”, Eliane Robert Moraes (1999) aponta para a leitura de Sade feita pela geração de intelectuais europeus da segunda metade do século XX, que se via compelida a repensar as bases do humanismo: "A filosofia radicalmente anti-humanista do Marquês representava então uma possibilidade de aprofundar a reflexão no sentido de investigar as representações do mal que, expurgadas da cena simbólica, haviam retornado com força assassina na cena histórica".

Bataille $(2015$, p.22) afirma que a literatura é inorgânica: "Sendo inorgânica, ela é irresponsável. Nada repousa sobre ela. Ela pode dizer tudo", isso porque, ao espremê-la, não sairá sangue; ao se cortar na carne, não se estará enterrando a espada no lombo do touro "até que se molhem os dedos" (Leiris, 2001, p.43) (descrição, aliás, bastante erótica). No entanto, na dissolução do código retórico, no encaminhando da linguagem para sua ruína, a literatura é culpada, advertiu-nos Bataille: culpada de trair o discurso, culpada de prescrever a moral, de exceder os sentidos, de transbordar os limites, de seu gasto improdutivo, de seu gozo frívolo.

É, aliás, o princípio da perda, a noção de dispêndio que Bataille (2013) elege para desenvolver seu tratado da economia humana e expor sua visão sistemática do mundo em $A$ parte maldita, em contraste com a economia clássica 
da aquisição. Os ritos sacrificiais das antigas civilizações, sobretudo as mexicanas e, em especial, o Potlatch, ${ }^{10}$ das tribos do noroeste da América do Norte, como "poder de perder", serão privilegiados na medida em que o dispêndio ali praticado subverte a ordem da acumulação para a ordem do gasto improdutivo, criando uma suspensão das atividades produtivas em favor do jogo, da festa. Há, na sociedade humana, observa Bataille (2013, p.20), o "interesse em perdas consideráveis, em catástrofes que provoquem, de acordo com necessidades definidas, depressões tumultuosas, crises de angústia e, em última análise, um certo estado orgíaco" (grifos do original).

Corromper o arquivo civilizatório pela tinta de sua pena, transgredir as convenções de modo que se desorganizem as estruturas de poder sustentadas por uma ordem discursiva e simbólica. A tradição se constitui sobre e com o arquivo, pelos arquivamentos promovidos pelo poder e pelo arconte; a pulsão de morte ou o mal de arquivo, por sua vez, seriam “anarquívicos” ou "arquiviolíticos”, destruidores do arquivo, segundo Derrida (2001, p.21). A operação textual de Sade tratará de rastrear todos os possíveis usos da língua, e não apenas seus usos convencionais, fazendo da literatura erótica o terreno privilegiado para revelar, ao destruir, novas configurações e disparar sensações inéditas. Daí a dimensão inaugural do gesto sadiano, a originalidade de seu empreendimento.

Roland Barthes (1979, p.36), em seu ensaio sobre Sade, cita um trecho em que o autor libertino teria escrito: "Para reunir o incesto, o adultério, a sodomia e o sacrilégio ele, com uma hóstia, enraba a filha casada". Parece haver aí também um jogo de espelhos que multiplica ao infinito os efeitos de representação, não sem distorcer a imagem a partir da corrupção do arquivo ofertado à civilização ocidental e de uma reorganização por meio da transgressão dos signos. Aquilo que a linguagem - seus nomes e desígnios - torna proibitivo é também o que ela pode ultrapassar e reconfigurar, inaugurando novas disposições. Em Sade, essa multiplicação se dá pela atividade erótica: “É a frase (os seus resumos, correlações internas, figuras, a sua sucessão soberana) que liberta as surpresas da combinação erótica e converte a rede do crime em árvore maravilhosa", diz Barthes (1979, p.36).

O ideal erótico - seu efeito semeador - seria que todos pudessem manter relações sexuais entre si, sem interdição de ordem parental, etária, corpórea, de gênero, classe, numérica, ampliando e proliferando as possíveis conexões sintáticas e semânticas na gramática dos corpos e da letra, nas catalogações e protocolos do arquivo erótico. Essa ideia é apresentada por Susan Sontag (1987, p.22) em “A imaginação pornográfica”, de 1967:

O universo proposto pela imaginação pornográfica é um universo total. Tem o poder de ingerir, metamorfosear e traduzir todas as preocupações com que é alimentado, convertendo tudo à única moeda negociável do imperativo erótico. Toda ação é concebida como uma série de intercâmbios sexuais. De tal modo, a razão pela qual a pornografia se recusa a fazer distinções fixas entre os sexos, ou a permitir que qualquer gênero de preferên- 
cia ou proibição sexual permaneça, pode ser explicada "estruturalmente". A bissexualidade, o desrespeito pelo tabu do incesto e outros traços similares comuns às narrativas pornográficas funcionam para multiplicar as possibilidades de troca. No plano ideal, seria possível a toda pessoa manter relação sexual com qualquer outra. (grifo do original)

No entanto, é também a interdição que, em sua potência organizadora, fornece o contorno do erotismo. Nesse mesmo texto, Sontag (1987, p.67) afirma que o erotismo - ou a pornografia, entendendo a distinção entre os termos de caráter estritamente moral - tem a ver com a restrição relativa à atividade erótica: "A simples explicitação dos órgãos e atos sexuais não é necessariamente obscena; apenas passa a sê-lo quando é realizada em um tom particular, quando adquiriu uma certa ressonância moral". Assim, a pornografia diria respeito a trabalhos de arte que incorporam a ideia de que a lascívia ou os pensamentos luxuriosos são imorais. Quando não se tem consciência de um julgamento moral contra o comportamento sexual, por sua vez, não se pode considerar erótico determinado trabalho artístico. Reforça-se, dessa forma, o caráter inquietante do erotismo, de modo que a liberdade e o limite, a lei e sua traição, a pulsão de vida e a de morte, a conservação, a destruição e a invenção coincidem.

Em "Arquivos literários e reinvenção da literatura comparada", Reinaldo Marques (2015, p.221-2) trata do arquivo literário como "espaço aberto e inacabado, zona de contato e relações entre distintas temporalidades e subjetividades, "capaz de promover descontinuidades e estranhamentos em relação ao tempo presente, ao ativar anacronismos potencialmente problematizadores da racionalidade arcôntica, estatal e científica, da evidência histórica”. Trata-se, assim, de escovar a história a contrapelo, para usar expressão benjaminiana: ao se operar um movimento inverso ao sentido oficial da história, é possível vislumbrar os espaços e as matérias encobertas, o que transita na superfície, está aderido à pele, em contato com o que, não raro, sua e fede, de modo a denunciar o que tem aparência asseada e apresentar uma nova disposição, menos organizada em relação ao padrão instituído pela "racionalidade arcôntica", à sua pretensão de verdade, a seus métodos e valores. Aparece, assim, a figura do "anarquivista", termo cunhado por Reinaldo Marques na esteira da pulsão "arquiviolítica" e "anarquívica" pensada por Derrida, em que arquivista e anarquista se reúnem para formar o pesquisador desejável - aquele que conhece as leis e as normas às quais o arquivo está submetido, mas que poderá transgredi-las a fim de encontrar novas relações, estabelecer contatos e fricções que lançam o arquivo a um futuro sem as leis e as lógicas que ora o regem.

\section{Resquícios do mal}

$\mathrm{O}$ arquivo Sade só poderia ser lido no século XXI de uma perspectiva anarquivista ou arquiviolítica, de forma que sua literatura, sua filosofia e sua controversa figura histórica fossem tomadas de modo anacrônico e desterritorializado, e respondessem a novas urgências, formulando relações diferentes daquelas do 
século XVIII, quando revelava as hipocrisias sociais, políticas e religiosas que perpassavam tanto o Antigo Regime quanto a França iluminista, ou mesmo daquelas do século XX da França, em que se buscava uma voz dissonante para inverter e redimir a catástrofe europeia. Oferecido ao futuro, Sade desafia - pela literatura - princípios e noções, formas e regras caras à civilização ocidental? $\mathrm{O}$ título do ensaio já citado de Michel Delon (2015) - "Sade, um humanismo possível?" -, ao trazer uma pergunta, indica a concepção de um humanismo outro, em alternativa àquele que teria sucumbido e que enfrentava sua pior crise no pós-Segunda Guerra, na descrença total em relação ao humano - ou determinado humano -, um projeto fracassado.

Contador Borges $(2015$, p.218), no posfácio à sua tradução de $A$ filosofia na alcova, afirma que, apesar de toda a crueldade em Sade, ele nos faz sonhar, isso porque a palavra sadiana corresponderia à própria imaginação. Como se trata de operação de valor sobretudo estético, a crueldade em Sade, diz o pesquisador, é apenas uma estratégia de negação do mundo, uma forma de demonstrar seus equívocos e quão distante ele se encontra do ideal de felicidade humana. Vista desse modo, aponta Borges (2015, p.218), "sua crueldade talvez pareça 'menos horrível' e seu 'sadismo' possa ser visto menos como um conjunto de perversões patológicas do que como o emblema de uma operação textual de grandes efeitos que traz em seu bojo um arranjo inusitado e terrível entre a razão e o sonho".

Michel Delon, após listar nomes de filósofos e ensaístas franceses que se debruçaram sobre a obra de Sade e que também lutaram contra o fascismo e os regimes de opressão, cita uma observação de Maurice Nadeau, ${ }^{11}$ que publica, em 1947, uma antologia de Sade: "A obra de Sade convém menos ainda aos cúmplices do Terror, aos adeptos da vontade de poder, aos fascistas, aos torturadores dos campos de concentração". "Como", ele pergunta, "os detratores de Sade puderam arriscar uma assimilação tão grosseira?" E responde: "Sua obra e sua vida se inscrevem, ao contrário, na contramão dos destruidores modernos da espécie humana, contra os carcereiros e os carrascos, contra todos aqueles que matam e prendem legalmente" (Nadeau apud Delon, 2015, p.40).

A recusa sadiana em relação às disciplinas dos homens e a favor da liberdade das paixões oferece possíveis modos de não sucumbir a discursos conservadores que tratam o bem e a lei como valores abstratos e transcendentais. Em vez disso, incita a buscar um trajeto contra-hegemônico capaz de desestabilizar determinadas estruturas para a abertura de novas formas de vida, abafadas pelas convenções sustentadas pelo poder e pela distinção. Sade, um nobre indomável do século XVIII, defensor das liberdades individuais, "feroz inimigo de qualquer ideia de crime legal, com seu ódio às leis e sobretudo à pena de morte" (Peixoto, 1979, p.15), teve, na literatura erótica, seu território de atuação política, seu enfrentamento indisciplinado à repressão que se confunde com natureza, ordem e instituição. Para Fernando Peixoto (1979, p.15), "Sade é a expressão 
literária de uma revolta total e quase metafísica, a reivindicação de liberdade não só de princípios mas principalmente de instintos". Assim, pode-se pensar a perversão nos romances sadianos como a contraface do mundo das ordens bem instituídas, geralmente remetidas a um instrumento de poder e subordinação, aos poderosos investidos em manter seus privilégios na ordem assegurada por leis e instituições repressivas e de aparência definitiva. Contudo, é também nos romances de Sade que encontramos diversas relações sexuais não consentidas, em que há gozo por parte de quem pratica a violência, mas não por parte daquele que a sofre. É Sade quem submete a flagelações Rose Keller, que ficou conhecida como a pedinte ou a mendiga que prestou queixa contra o marquês, em 1768, levando-o ao encarceramento. Portanto, há não somente uma face libertária e reveladora da falsidade do bem nas operações sadianas mas também um individualismo irresponsável destruidor de parcela do arquivo civilizatório que convém conservar. Assim, qual será esse limite e quem vai ditá-lo, na medida em que se trata de um território em disputa? Eis nossa inescapável danação.

Figura altamente controversa, geralmente tomada no limite da condenação e da veneração, o marquês de Sade foi uma referência importante para o pensamento do século $\mathrm{XX},{ }^{12}$ sobretudo para as vanguardas francesas que celebraram o aspecto transgressivo e anti-institucional de sua obra, sendo, conforme observou Daniel Serravalle de Sá (2008, p.365), “[...] quem sabe, o único criminoso da história literária a ser estudado, legitimamente, em termos filosóficos e intelectuais". No avançar do século XXI, que contribuição poderíamos recolher dessa personagem histórica? Numa época em que os discursos de benevolência e dos chamados cidadãos de bem geram cada vez mais desconfiança, o mal, a morte, $o$ apagamento, a destruição se apresentam como estratégias de destituição de determinados valores e de reinvenção de novos/mesmos arquivos, esses "penhores do futuro". ${ }^{13}$

O "Evangelho do Mal", como Jean Paulhan chama Os 120 dias de Sodoma. A crítica sistemática da concepção clássica de arquivo com base na ideia de Mal de arquivo (Mal d'archive). A literatura e o mal (La Littérature et le mal) - segundo Georges Bataille, para livrá-la da subordinação, do moralismo e do tédio. Talvez seja interessante pensar no potencial político e de resistência desse sinal invertido da positividade, ${ }^{14}$ que visa sobretudo evidenciar as unidades de sentido que nos formam, a partir das quais podemos identificar também os princípios de sua destruição - ou desconstrução, para usar uma ideia cara à Derrida. Dolmancé, um dos preceptores imorais de Eugênia, afirma no terceiro diálogo de A filosofia na alcova: "Não se pode sempre fazer o mal. Privados do prazer que ele dá, equiparemos ao menos essa sensação à pequena maldade picante de jamais fazer o bem" (Sade, 2015, p.47). 


\section{Notas}

1 Esta é sobretudo uma leitura do erótico feita por Georges Bataille.

2 Retomada do artigo "Le Secret de Sade" [O segredo de Sade], publicado nos n.1516 (ago.-set.) e 17 (out.) da revista Critique, em 1947. (Nota dos editores da edição brasileira de La Littérature et le mal - Bataille, 2015, p.97)

3 Informação presente na nota de rodapé n.6 do ensaio "Sade", de A literatura e o mal (Bataille, 2015, p.103).

4 Várias fontes dão conta dessa informação. A principal referência para a elaboração deste parágrafo se encontra em $A$ parte obscura de nós mesmos: uma história dos perversos (Roudinesco, 2008).

5 Trata-se da edição da coleção Pérolas Furiosas, da editora Iluminuras, dirigida por Contador Borges, responsável pela tradução, pelo posfácio e pelas notas (Sade, 2015). Os outros livros de Sade publicados pela coleção são: Os 120 dias de Sodoma; Diálogo entre um padre e um moribundo: e outras diatribes e blasfêmias; Os infortúnios da virtude; e Justine: ou os tormentos da virtude.

6 Como autores do silêncio podemos apontar Beckett, Proust, Mallarmé.

7 Esse ensaio foi ilustrado por Andre Masson.

8 Organizador da edição La Pléiade.

9 A citação a Ilse Koch é feita por Michel Delon em referência ao livro de Michel Onfray La Passion de la méchanceté (2016). Nesse livro, Onfray critica a mitificação de Sade por intelectuais do século XX e das gerações seguintes, chamando de "vulgate freudienne" o fato de tomarem Sade por um escritor que transferiu a paixão pela maldade do plano real para o plano simbólico, indicando a história da cadela de Buchenwald como um tema de romance sadiano e tratando o escritor setecentista de feudal, misógino, falocêntrico e violento. Cito Onfray: “Tout le monde connaît les frasques d'Ilse Koch, mais peu savent son nom: les abat-jour en peau humaine dans les camps de concentration nazis, c'est elle - entre autres gestes maléfiques... La vie de cette femme racontée simplement, sans fioritures lyriques, mais avec la précision d'un anatomiste, donnerait un roman du marquis de Sade. Le tenants de la religion sadienne pousseront des cris: la littérature n'est pas le réel, la passion pour la méchanceté sur le papier dispenserait même le passage à l'acte! Sade ne fut pas sadique ni sadien, tout juste un grand écrivain fantasmant ce qu'il n'a pas fait! Vulgate freudienne..." (Trecho retirado da resenha do referido livro. Disponível em: <https://leslecturesdeninablog.wordpress.com/tag/michel-onfray>. Acesso em: 4 set. 2019). Michel Delon trata o livro de Onfray de "panfleto", indicando outra leitura do Marquês: o "[...] panfleto recente de Michel Onfray, que não hesita em comparar as heroínas celeradas de Sade a Ilse Koch, a cadela de Buchenwald. 'Os sadianos recusam essa assimilação entre a libertinagem do marquês e a da Comandante. Por quê? Há mais num romance de Sade do que nessa vida sadiana? Ou menos?' Não somente eles recusam tal assimilação, mas defendem a ideia de uma possível leitura liberadora dos romances de Sade" (Delon, 2015, p.38).

10 De acordo com o maior número de fontes consultadas, Potlatch, em chinook, quer dizer "presente" ou "ato de dar".

11 Crítico, editor e escritor francês, Maurice Nadeau (1911-2013) é autor de História do surrealismo (1945) e fundador da revista Quinzaine Littéraire (1966).

12 Autores que escreveram sobre Sade: Georges Bataille, Jacques Lacan, Michel Foucault, 
Gilles Deleuze, Philippe Sollers, Pierre Klossowski, Maurice Blanchot, Roland Barthes, Simone de Beauvoir, Jean Paulhan, Octavio Paz, entre outros. O filósofo francês Jacques Derrida, ao que parece, não escreveu sobre o marquês.

13 Em Mal de arquivo, Derrida (2001, p.31) observa: “O arquivo sempre foi um penhor, e como todo penhor, um penhor de futuro. Mais trivialmente: não se vive mais da mesma maneira aquilo que não se arquiva da mesma maneira. O sentido arquivável se deixa também, e de antemão, codeterminar pela estrutura arquivante. Ele começa no imprimente".

14 Como propõe Joel Birman (2008, p.109) no ensaio "Arquivo e mal de arquivo: uma leitura de Derrida sobre Freud”, “[...] o arquivo seria um conjunto de documentos estabelecidos como positividades, na sua materialidade, e que seria ainda, na sua pretensa objetividade, o reflexo do que ocorreu de fato na experiência histórica. Portanto, como verdade de fato de uma dada tradição, o arquivo, na sua versão clássica, seria o monumento dessa tradição" (grifos do original).

\section{Referências}

ADORNO, T. Notas de literatura I. Trad. Jorge de Almeida. São Paulo: Editora 34, 2003.

BARTHES, R. Sade, Fourier e Loyola. Trad. Maria de Santa Cruz. São Paulo: Livraria Martins Fontes, 1979.

- Ograu zero da escritura: seguido de novos ensaios técnicos. Trad. Mario Laranjeira. São Paulo: Martins Fontes, 2004.

BATAIlle, G. A parte maldita - precedida de A noção de dispêndio. Trad. Fernando Scheibe. Belo Horizonte: Autêntica, 2013.

2015 . . A literatura e o mal. Trad. Fernando Scheibe. Belo Horizonte: Autêntica,

BEAUVOIR, S. de. Deve-se queimar Sade. Trad. Augusto de Sousa. São Paulo: Difel, 1961.

BIRMAN, J. Arquivo e mal de Arquivo: uma leitura de Derrida sobre Freud. Natureza Humana, v.10, n.1, p.105-28, 2008. Disponível em: <http://pepsic.bvsalud.org/pdf/ nh/vl0nl/v10nla05.pdf>. Acesso em: 4 set. 2019.4. Aline Leal Fernandes Barbosa - OK.rtf

BORGES, C. Posfácio. In: SADE, M. de. A filosofia na alcova. Trad. Contador Borges. São Paulo: Iluminuras, 2015.

BORGES, J. L. Ficções. Trad. Carlos Nejar. São Paulo: Globo, 1999.

DELEUZE, G. Sacher Masoch: o frio e o cruel. Trad. Jorge Bastos. Rio de Janeiro: Zahar, 2009.

DELON, M. Sade, um humanismo possível? Cadernos de Ética e Filosofia Política, v.1, n.26, 2015. Disponível em: <http://www.revistas.usp.br/cefp/article/view/10867l>. Acesso em: 4 set. 2019.

DERRIDA, J. Mal de arquivo: uma impressão freudiana. Trad. Claudia de Moraes Rego. Rio de Janeiro: Relume Dumará, 2001. 
LEIRIS, M. O espelho da tauromaquia. Trad. Samuel Titan Jr. São Paulo: Cosac \& Naify, 2001.

MARQUES, R. Arquivos literários: teorias, histórias, desafios. Belo Horizonte: Ed. UFMG, 2015.

MORAES, E. R. A fera pensante. Folba de S.Paulo, 13.11.1999. Jornal de Resenhas. Disponível em: <https://wwwl.folha.uol.com.br/fsp/resenha/rs1311199912.htm>. Acesso em: 4 set. 2019.

. A prosa degenerada. Folha de S.Paulo, 10.5.2003. Jornal de Resenhas. Disponível em: <https://wwwl.folha.uol.com.br/fsp/resenha/rs1005200308.htm>. Acesso em: 4 set. 2019.

2006.

. Lições de Sade: ensaios sobre a imaginação libertina. São Paulo: Iluminuras,

PAZ, O. Um mais além erótico: Sade. Trad. Wladir Dupont. São Paulo: Mandarim, 1999.

PEIXOTO, F. Sade: vida e obra. Rio de Janeiro: Paz e Terra, 1979.

REVISTA Acéphale. A conjuração sagrada (v.1, 1936). Florianópolis: Cultura e Barbárie Editora, 2013.

ROUDINESCO, E. A parte obscura de nós mesmos - uma história dos perversos. Trad. André Telles. Rio de Janeiro: Editora Zahar, 2008.

SÁ, D. S. de. O Marquês de Sade e o romance filosófico do século XVIII. Eutomia Revista de Literatura e Linguística, v.1, n.2, 2008, p.362-77. Disponível em: <4. Aline Leal Fernandes Barbosa - OK.rtfhttps://periodicos.ufpe.br/revistas/EUTOMIA/ article/viewFile/1948/1514>. Acesso em: 4 set. 2019.

SADE, M. de. A filosofia na alcova. Trad. Contador Borges. São Paulo: Iluminuras, 2015.

Os 120 dias de Sodoma. Trad. Alain François. São Paulo: Iluminuras, 2017.

. Justine ou os tormentos da virtude. Trad. Marcela Vieira e Eduardo Jorge de Oliveira. São Paulo: Iluminuras, 2019.

SONTAG, S. A imaginação pornográfica. In: A vontade radical: estilos. Trad. João Roberto Martins Filho. São Paulo: Companhia das Letras, 1987.

RESUMO - Neste artigo, o objetivo é pôr a obra e a vida do Marquês de Sade - em que impera a ideia de transgressão e de destruição - em contato com diversas noções de arquivo, sobretudo a de Jacques Derrida em Mal de arquivo, em que a pulsão de morte repousa no que é da ordem da conservação. Se a renovação com base em novas consignações é a condição de posteridade do arquivo, de que modo podemos ler Sade no século XXI?

PALAVRAS-CHAVE: Marquês de Sade, Arquivo, Erotismo, Derrida, Espelhos.

ABSTRACT - The article puts in contact the works and life of the Marquis de Sade - in whom the idea of transgression and destruction prevails - and several notions of archive, 
especially that of Jacques Derrida in Archive fever, in which the death drive rests upon what pertains to the order of conservation. If renewal from new consignments is the archive's posterity condition, how can we read Sade in the $21^{\text {st }}$ century?

KEYWORDS: Marquis de Sade, Archive, Eroticism, Derrida, Mirrors.

Aline Leal Fernandes Barbosa é bolsista do Programa Nacional de Pós-Doutorado da Capes na Pontifícia Universidade Católica do Rio de Janeiro. É mestra e doutora pela mesma instituição. @- alinelfbarbosa@gmail.com /

https://orcid.org/0000-0001-5488-0654

Recebido em 6.1.2020 e aceito em 17.2.2020.

A autora agradece as contribuições dadas ao texto pelo grupo de orientação da Profa. Dra. Rosana Kohl Bines (PUC-Rio).

I Programa Nacional de Pós-Doutorado Capes, Pontifícia Universidade Católica do Rio de Janeiro, Rio de Janeiro, Brasil. 